\title{
religion \\ .

\section{Review of Anna C. Korteweg and Jennifer A. Selby (eds.), Debating Sharia: Islam, Gender Politics, and Family Law Arbitration, Toronto: University of Toronto Press 2012, 397 pp., ISBN 978-1-4426-4262-1}

\author{
By Nadia Sonneveld, Radboud Universiteit Nijmegen, the Netherlands
}

In 2003, the spokesperson for the Institute for Islamic Civil Justice (IICJ) announced that, in line with provincial regulations concerning arbitration, the institute would offer shari'a-based arbitration to Muslims in family law matters. This announcement was the start of a heated public debate, which persisted even after the Ontario government stated on 11 September 2005 that it would abolish all forms of faith-based arbitration in the province. In Debating Sharia, editors Anna Korteweg and Jennifer Selby analyse this public debate. The book consists of twelve chapters, which are written by scholars and activists from various disciplines. The first two chapters comprise Part 1, which offers the reader ethnographic accounts of religious divorce among North American Muslims. Chapters 3 and 4 assess the Canadian legal context (Part 2), Chapters 5 and 6 the issue of arbitration and religious authority within Islam (Part 3). The following four chapters (Part 4 and 5) focus on the public debate itself and the complicacies, which partaking in the public debate as both a scholar and an activist entail (Chapters 7 and 8) as well as the way in which the public debate informed the racialisation of Canadian Muslims (Chapters 9 and 10). In Chapters 11 and 12 (Part 6), the debate is analysed in the context of multiculturalism (Chapter 11) and secularism (Chapter 12).

Korteweg (associate professor of Sociology at the University of Toronto) and Selby (assistant professor of religious studies at Memorial University of Newfoundland) depart from the premise that the debate surrounding shari'a-based arbitration failed to address important issues such as multiculturalism, secularism, and women's rights in Islam in a productive way. In the book they aim at highlighting the discrepancy between what was stated in the public debate and the everyday realities of faith-based arbitration. In doing so, they claim to have laid the groundwork for conducting the debate on shari'a in the West in a more insightful and informative manner.

This work is licensed under a Creative Commons Attribution License (3.0)

Religion and Gender | ISSN: 1878-5417 | www.religionandgender.org | Igitur publishing 
For example, if the book shows anything, it is the need for the government to come to terms with its own understanding of multiculturalism and secularism. With regard to the concept of multiculturalism, Alexandra Brown (Chapter 11) describes how the Ontario Sharia debate actually started in 1991 with the introduction of the provincial Ontario Arbitration Act, which allowed parties to negotiate an agreement on their own terms with regard to family law matters, the so-called 'domestic contracts'. Rather than considering the Sharia debate in terms of a longer history of negotiation over private arbitration, Brown convincingly argues that the way the government responded to the debate made it appear as if the IICJ announcement was the cause of all consternation. In reality, however, it was the provincial government itself that had created a form of multiculturalism 'from above' (through the enactment of the 1991 Arbitration Act), a fact, which it tried to conceal by operating as the skillful manager in the Ontario Sharia debate.

In her chapter on secularism (Chapter 12), Jennifer Selby demonstrates that while the provincial government favoured the 'one [secular] law for all' approach in the Ontario Sharia debate, it saw no fault in continuing public funding of private Catholic schools in Ontario in the 2007 'One School' debate. This, she maintains, highlights the continuing Christian biases within so-called neutral secularism. Audrey Macklin (Chapter 3) convincingly argues that the idea of 'one law for all' only holds if the constraints, which religious and cultural norms pose on the so-called 'encultured subject' (the Muslim woman possessed by her culture and religion), do not affect her non-religious counterpart, the so-called 'liberal subject' (the Western woman who possesses her culture). Persuasively showing this assumption to be false, for Macklin it is not obvious why '...ostensibly unjust private contracts based on religious principles would or should warrant greater concern than similarly unfair private contracts based on secular principles' (2012: 115).

In Chapter 4, lawyer and activist Faisal Kutty moves from the government to another important player in the public debate: the different Muslim activists, who were divided over the question whether or not faith-based arbitration should be allowed. Here Kutty raises the interesting question as to why feminists, who engage in active re-interpretation of the sources of shari'a (for an example see Chapter 7 by Nevin Reda), were so opposed to faith-based arbitration. They, Kutty argues, missed an opportunity to indigenise Islam in Canada. Here, however, Kutty overlooks an important issue, one that is convincingly taken up by $\mathrm{L}$. Clarke (Chapter 5), namely, the issue of religious authority. In the context of indigenisation of Islam in Canada, the question arises what Muslim immigrants will take from outside and make their own, and, most importantly, whether there is a religious authority who decides what can and cannot be incorporated.

Except for Clarke, who claims that everywhere in the Muslim world religious authority is put into question and, hence, Islamic law is under construction, throughout the book, the reader is given the incorrect impression that innovation and flexibility in Islam are merely features pertaining to Canadian or Western Islam (see also the foreword by Jocelyne Cesari). For example, Anver Emon (Chapter 6) uses the example of British India and argues that the colonial's administration reductive readings of the sources of the shari'a became a blueprint for the post-independence Indian government, which not only left the colonial interpretation of Islamic law intact, but in the face of ongoing Western hegemony, even turned it into the basis of Muslim identity. Islamic

Religion and Gender vol. 4, no. 1 (2014), pp. 80-82 
law, Emon seems to suggest, is not so flexible after all, at least not in the nonWestern context.

Offering ethnographic accounts of divorce practices among Canadian and American Muslim women, Julie Macfarlane (Chapter 1) and Christopher Cutting (Chapter 2) show that shari'a in Canada is flexible in the sense that women can shop around until they find an imam who is willing to accommodate their wishes. This phenomenon, which Macfarlane calls imam-shopping, shows that women are not legally bound by the outcome of an imam's deliberation. Instead, Cutting argues, in practice the most pressing issue is not faith-based arbitration, but rather Muslim women's wish to obtain religious divorce through the help and/ or mediation by an imam. This forceful conclusion renders the IICJ announcement to offer arbitration and the ensuing Ontario Sharia debate obsolete and beside the point.

However, while the phenomenon of imam-shopping might indeed be indicative of the flexibility of Islam in the West, it simultaneously raises many questions on religious authority in North American Islam. For instance, do women see imams as religious authorities - which Cutty and Macfarlane seem to suggest - or merely use them as tools in their quest for a religious divorce? Relatedly, what role does the Internet play, and do women meet religious authorities online? If yes, who are these authorities and do women meet them before they meet an imam offline? More extensive ethnographic accounts on the subject of religious authority in these two chapters would have contributed to the topic coherence of the book and would have benefited the internal relationship between the different chapters.

In the context of the Ontario Sharia debate, it is important to know how imams interpret the principles of the shari'a and whether age, level of education, and country of origin are of influence on the outcome. Whereas Cutting remarks that in general imams elect their opinions from within the four schools of Sunni law, Macfarlane somewhat vaguely states that the imams' primary source of advice is the Quran as well as the different teachings of the four schools of law. It remains unclear whether imams take the (often) shari'a-based family law codes prevalent in the (relevant) countries of origin as a point of reference too. Over the past decades, most Muslim majority countries witnessed significant reforms in family law matters, divorce especially. For example, in 1967 Pakistani women were given the right to divorce without the consent of the husband and without the need to prove ground in court through a procedure called khul'. This divorce reform (and other reforms) not only shows that innovation and flexibility of shari'a are features pertaining to both the Muslim and the non-Muslim world, given the fact that most Muslim women from the greater Ontario Area have a Pakistani background, it might also have a positive impact on the way in which Ontario Muslim women (wish to) obtain a religious divorce. In this respect, an opportunity is missed to grapple the issue of women's rights in more detail and gain a better understanding of the complex relationship between religion and gender in North America.

In general, however, Debating Sharia does indeed lay the groundwork for conducting the debate on shari'a in the West, including such issues as multiculturalism, secularism, and the rights of Muslim women in Islam, in an informative and productive manner. Korteweg and Selby have made an important contribution to research on a matter of significant public and academic concern. 